\title{
THE WAY TO DESIGN WEB-BASED (EMP) COURSE IN EFL CONTEXT: A BRIDGE FROM EVALUATION TO COURSE DESIGN
}

ABSTRACT. As the worldwide use of English increases it has become indispensable in educational, vocational and professional environments. As a result, English for specific purposes (ESP) has a central role in teaching English at the tertiary level. With rapid advances in technological development, technology has emerged as one of the key aspects of teaching and learning English in classrooms. Based on the students' needs to use technology in learning English for medical purposes (EMP), the internet has turned into a valuable EMP resource. However, the selection of appropriate websites that match the learners' and teachers' needs can turn into a time-consuming process.

KEYWORDS: ESP; English for medical purposes; web-based learning.

\section{INTRODUCTION}

Today, English as a foreign or second language plays an essential role whether for educational, vocational, or professional purposes. As the global use of English is increasing, many learners want to learn English for particular purposes. Therefore, there is an increase

basim.alaish@yahoo.com.au

2 ghadamohamed.94gsz@gmail.com 
in the demand of ESP (English for Specific Purpose). ESP refers to the teaching and learning of English for particular purposes (Day \& Krzanowski, 2011). ESP has a central role in teaching English at the university level (Hyland, 2002). Hence, ESP proficiency is essential as in most universities students are required to study the majority of their subjects in English, since English is a dominant language in the fields of science, engineering, business, medicine, etc.

Indeed, most ESP textbooks in the market are insufficient for motivating and engaging students in the classroom. Significantly, over the last decades of the twentieth century, the learning and teaching of English witnessed many changes due to the influence of technology. According to a study carried out to explore previous studies on the technology use in ESP classrooms, the use of technology reported an increase in the quality of students' comprehension and language abilities (Dashtestani \& Stojkovic, 2015). The use of technology in ESP instruction can enable and encourage students to be more in class. In addition, the class would be learner-centered, so the student would be actively engaged.

\section{LITERATURE REVIEW}

\section{ESP DEFINITION AND BRIEF HISTORY}

English for specific purposes was first introduced in the 1960s. It was simply defined as the teaching and learning of English for any specific purpose. During that time ESP was limited to grammatical features and vocabulary. Then in the 1970s and 1980s there was a focus on the importance of language skills since grammatical and lexical features alone were not enough.

Therefore, the focus shifted to communicative language teaching and to learner-centered approach. According to Hutchison and Waters, ESP is an approach that focuses on the learner's purpose of learning English, in which all the content and methods is based on the learner's reason (Hutchinson \& Waters, 1987).

Over the last twenty years there was an increase in studies on the importance of ESP. Therefore, the definition of ESP is constantly changing and developments in theory and methodology arise. ESP now focuses more on language context rather than on grammar and language structure. An ESP course is developed according to 
the purposes and needs of the learners, not only connected to the learner's real world, but also integrated into a subject area that is relevant to the learner (Rahman, 2015).

\section{THE USE OF TECHNOLOGY IN ESP CONTEXT}

As technology rapidly advances, its emergence and application in teaching and learning comes into view in English classrooms. According to Shyamle and Phil (2012), it is proved that technology has a positive role by providing a wide access to different materials, activities, and techniques.

In recent years, there have been many developments in the ESP context. The use of technology has made an impact in ESP classrooms. It is claimed that a technologically enriched environment influences the performance of students, enhances their learning ability, provides beneficial language input, boosts students' motivation, and increases ESP proficiency (Vaiciuniene \& Uzpaliene, 2012).

Kavaliauskiene (2003) states that computers have become an effective means of education in our world today. Indeed, the notion of Information and Communication Technology (ICT) has been linked to the use of the internet, which offers a wide range of up to date information and materials to (ESP) learners.

The use of web-based programs in ESP context has shown positive results. In a study conducted by Kavaliauskiene (2003), the response of the ESP learners on learning English on the web has been positive. Another study investigated the students' perception on ESP websites. The results revealed that the majority showed positive attitude towards learning English through ESP websites (Kung \& Chuo, 2002).

Vaiciuniene \& Uzpaliene (2010) acknowledge the value of technology in ESP learning. On the basis of their research results, the web-based learning environment has a great impact on students' performance and improves their learning outcomes, offers authentic materials, which as a result, increases their motivation in the subject matter and develops their ESP proficiency.

A recent case study, conducted to assess the impact of the internet on ESP classrooms, has revealed encouraging results. The students' learning motivation was increased by using the internet and individual learning was highly promoted. Moreover, having an instant access to definitions, multimedia, and animations facilitat- 
ed the learners' comprehension of texts and improved their reading and listening skills (Lavinia, 2017).

\section{PURPOSE OF STUDY}

Since English for medical purposes (EMP) is vital for the future studies and careers of medical students, this subject area was selected specifically for the current study. it is known in the medical field, almost all the subjects are taught in English, which shows the importance of learning EMP. Additionally, in their future profession, the students will be required to use English in communication. Even though English plays an essential role in the field of medicine and English courses are offered widely in different levels in medical schools, most medical students face obstacles with learning and communicating effectively in English.

According to the results of the authors' previous needs analysis study which was conducted at the Faculty of Medicine, University of Benghazi Al Marj Campus, Libya, textbooks did not fully meet the needs of the students. First, the teachers used grammar-translation method; therefore, the classroom was not centered on the learner so the students did not have the opportunity to be involved actively in the class. Secondly, following the textbook caused some students to be distracted from the class, since they have mentioned reading only did not help in being focused during the lesson. Significantly, from the outcome of the needs analysis, $86 \%$ of the students preferred the use of technology in learning English. They have pointed out that technology would assist them more effectively in learning English, since in our modern world today, technology provides a wide variety of access to different information and activities for students. Therefore, as a result of the students' needs and also to the influence of technology in language learning, this paper will present a sample of web-based (EMP) program which has been designed for Medical students according to their needs preceded by an evaluation process of one existing online program as an essential step for preparing an online course design. 
In recent years, technology in learning and teaching is widely used in language classrooms. The internet access provided a wide range of materials for ESP learners; however, some students find it difficult and time consuming to find materials relevant to their needs (Vaiciuniene \& Uzpaliene, 2010). Therefore, it is the teachers' role to guide the students by providing authentic sources and evaluating the programs in order to make sure they meet their requirements and educational needs and goals. Hubbard (2006) defines evaluation as the process of investigating a CALL (Computer Assisted Language Learning) software to judge its appropriateness, identify the ways it may be effectively implemented, to assess its degree of success and to decide whether it can be used or modified for future use.

In regard to our selection of this subject area, we believe that learning English for medical purposes is essential for medical students for both their studies and occupation. In the $20^{\text {th }}$ century, English has become broadly used in the medical field (Pavel, 2014). Therefore, medical students need to learn English for different goals such as research, reading medical books and journals, and use in their everyday practice (Abdullah, 2005). Lahti et al. (2014) stated that computer-assisted language learning methods have been widely used in the medical education. Therefore, using technology to increase the motivation of EMP learners by providing suitable learning websites can contribute to the development of their English language proficiency. Thus, website evaluation would be purposeful in selecting appropriate materials and online courses that match students' requirements and needs.

In our own context, the website we evaluated is aimed at university medical students. The students have the same mother tongue and are all from the same cultural background. Their level of English is intermediate and they have basic computer skills. Accordingly, the course for this group of students is English for medical purposes (EMP). The content of the course focuses on all the four language skills. Medical student are not only expected to have sufficient knowledge of English during their study and their future career, but also to be able to use the language effectively. Thus, the website we have evaluated and selected for our own context is an 
online medical course that focuses on the four English language skills. It provides reading, writing, listening, and speaking activities.

Levy and Stockwell (2006) have identified three major types of CALL software evaluation: checklists or forms, frameworks, and designer's evaluation. There is a considerable difference between these approaches in terms of simplicity, focus, and application. In our evaluation, we have used the checklist to evaluate the website for authorship, accuracy, purpose, content, currency, design, organization, and its ease of use for novice teachers to determine whether or not a particular site should be considered for their students.

Our evaluation checklist was divided into five sections. The first section is about the authorship and accuracy. It is important to find out the author's identity and his or her qualification or expertise in order to determine the credibility and reliability of the information. The second section is the program in regard to its material, design, and arrangement. The third section deals with the teaching perspective, whether it can be applicable for use in the classroom and what the teachers' role in the program is. The fourth section deals with the learners' perspective in relation to the suitability of the content to meet their academic requirements, expectations, and needs; additionally, whether the program contains a variety of learning strategies. The last section is the overall judgment to determine the quality and usability of the program in the teaching and learning of English. For more details see Appendix (1).

The website (www.medicalenglish.com) that we have evaluated was an online course aimed at medical students. It was targeted for students with intermediate level of English. In order to gain access to the activities and lessons in the program, the learner was required to register. The students were only required to provide their name, email, and password which was a basic and simple way of registration. The reason for having to make an account is so that the student can save their progress.. Concerning the presentation of the website, it was well-designed, organised, and simple to use. The navigation is not complicated and allows quick access to other pages including the home page. In regard to the content and material, there were 20 units in the program and each had a theme. In each theme, there was a variety of activities that focused on the four language skills. Moreover, the website contains audios, videos, and a dictionary. There is also a download icon which allows the user to download the videos and sound tracks available in the course. Clearly, this online course is not just beneficial for students, 
but also for teachers. They can adopt the content of the website to use in their classrooms. Additionally, at the end of the 20 units, the learner is given a certificate as a motivating reward for their hard work in passing the course (Appendix 1).

\section{WEB DESIGN}

According to Hubbard (2006), the purpose of doing an evaluation is to investigate any software to check its appropriateness, to identify ways it can be efficient for implementation, whether it can be used or adjusted. However, because there are many resources available for students on the internet, to locate useful websites that are relevant to the students' needs may require time and high English proficiency in order to analyze the available websites (Simin, 2012). Since some students have limited language ability, it is important for teachers to guide students to suitable websites. Therefore, based on the results of the evaluation of EMP websites, we have created a website for medical students in our own context which is suitable and appropriate for the needs we have studied earlier.

The website (english4medical) that we have created is intended for medical students with an intermediate level of English. The knowledge of English language is important for the future doctors not only for getting the necessary information from books and the internet, but also for the successful communication with their foreign colleagues and patients. Since many students face difficulty in learning Medical English when entering the university, this website aims to help them with their medical vocabulary, and more importantly, to help them improve all four language skills (i.e. reading, writing, speaking, and listening). The reason for this is that a medical student is required to write and read in English in their field of study and profession, and communicate with colleagues in English. Therefore, this website follows the CLT (communicative language teaching) method in teaching English for medicine.

To create our website, we used the Wix site (Free website builder) and the Hot potatoes program (Free software) to create exercises to embed them in our web-based course. The website contains a menu of 6 main buttons each with its own purpose. They are located at the top of every page to make it easier for the user to navigate from one page to another. The first button leads to the home page which includes information about the website, so that the user would 
know why this website was created. Then there is the contact icon, where learners or teachers can contact the creators for help or inquiry. Then follows the Guide button which gives instructions to students and teachers how to use the website and the different materials. Then there is the Lessons icon which contains a list of 10 lessons each based on a different theme that features different exercises and activities. Moreover, a Dictionary button was made to help students with finding out the meaning of new medical terms. The last button is the Resources which provides students and teachers with different medical books and websites (Picture1).

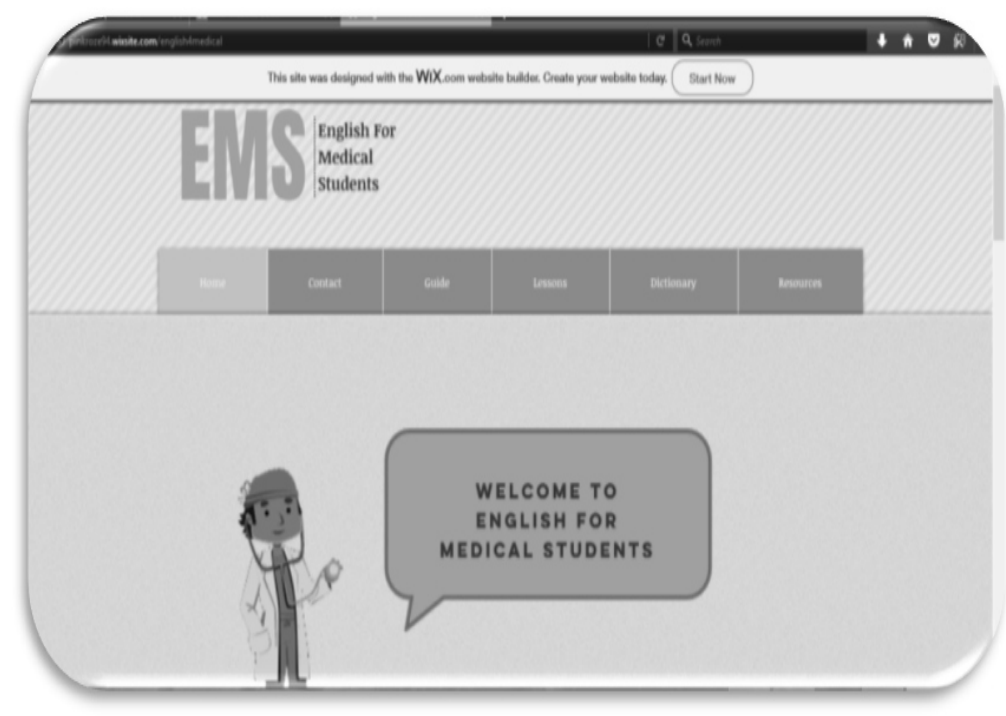

PictuRe (1)

Regarding the lessons, the student has to start with the first lesson then continue the lessons in order (i.e. from Lesson1: Health \& illness to Lesson 10: Respiratory System). Each lesson is based on a theme, and in each one you will find a reading passage where a student reads along with the audio track available on the page. The passage is followed by comprehension exercises (Picture 2).

After reading comes the writing section, in which a student will find a grammar rule explained including examples from the reading passage. Next, there is an exercise to enable the student to practice their sentence structure using the grammatical rule they have learnt. Additionally, they are given new medical vocabulary 


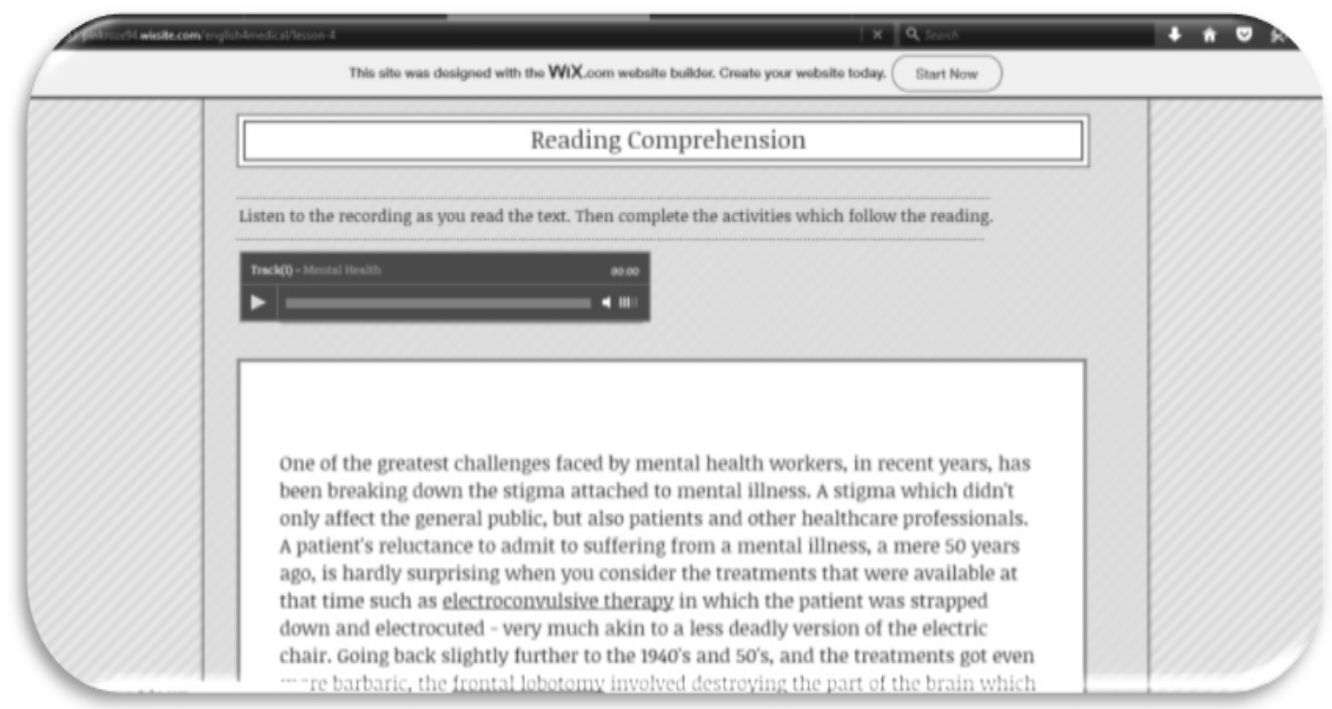

Picture (2)

list which are related to the theme of the lesson followed by exercises to get them to practice the usage of these terms (Picture 3).

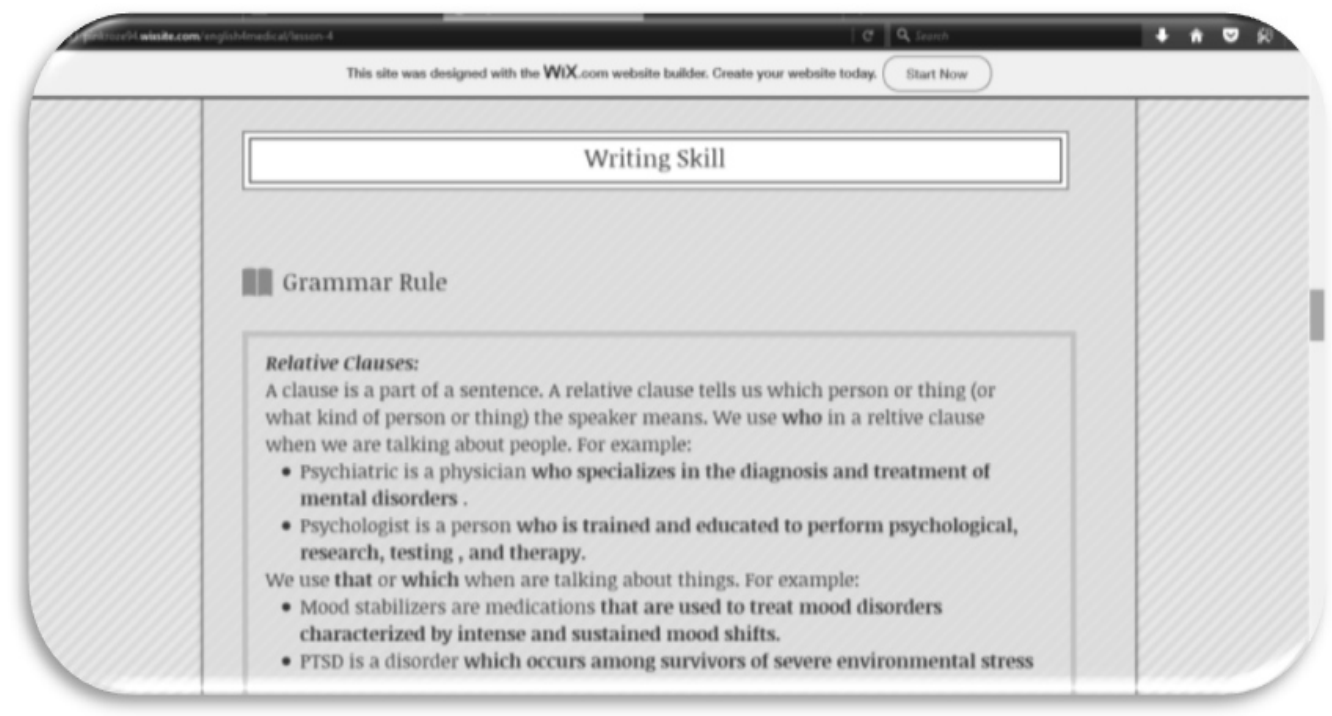

PiCTURE (3)

The third part is listening where the learner gets to listen to an audio or video, and answer the questions. Additionally, a (pdf) file 
containing the correct answers is offered after the questions, so that the students can check their answers (Picture 4).

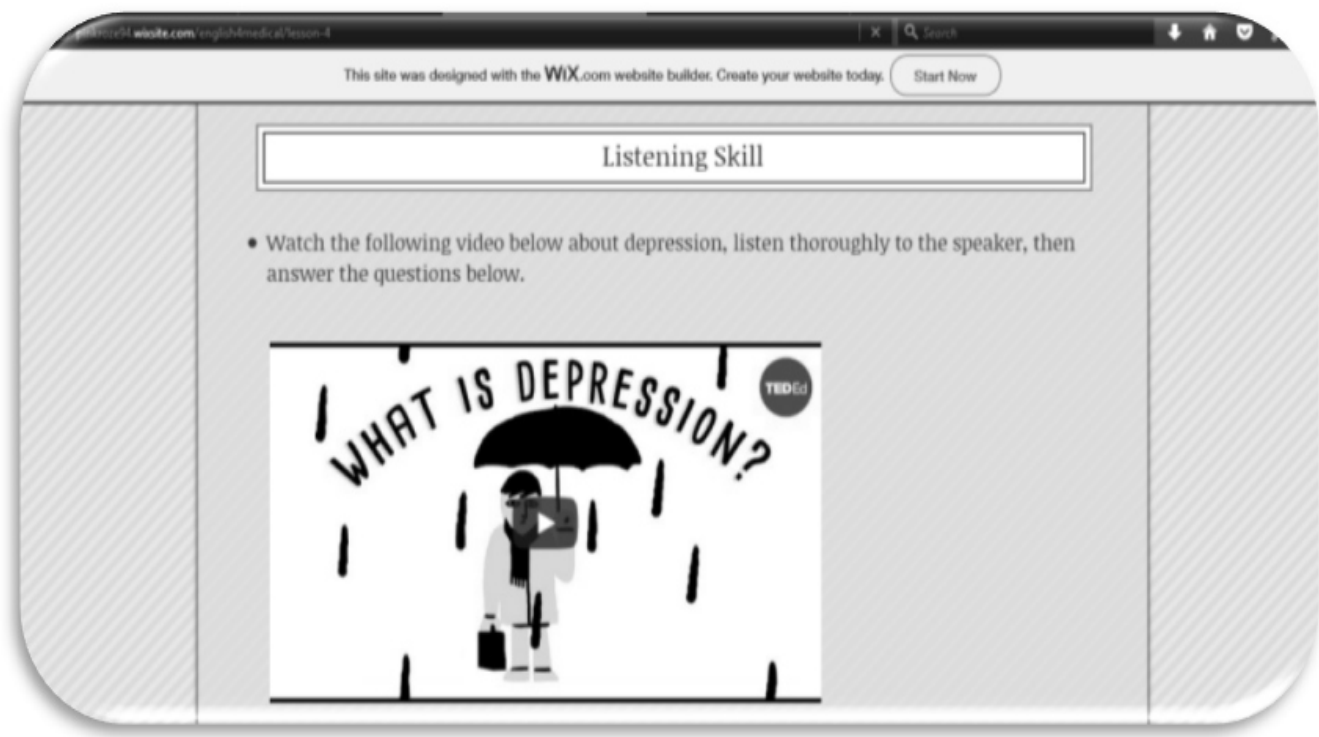

PiCTURE (4)

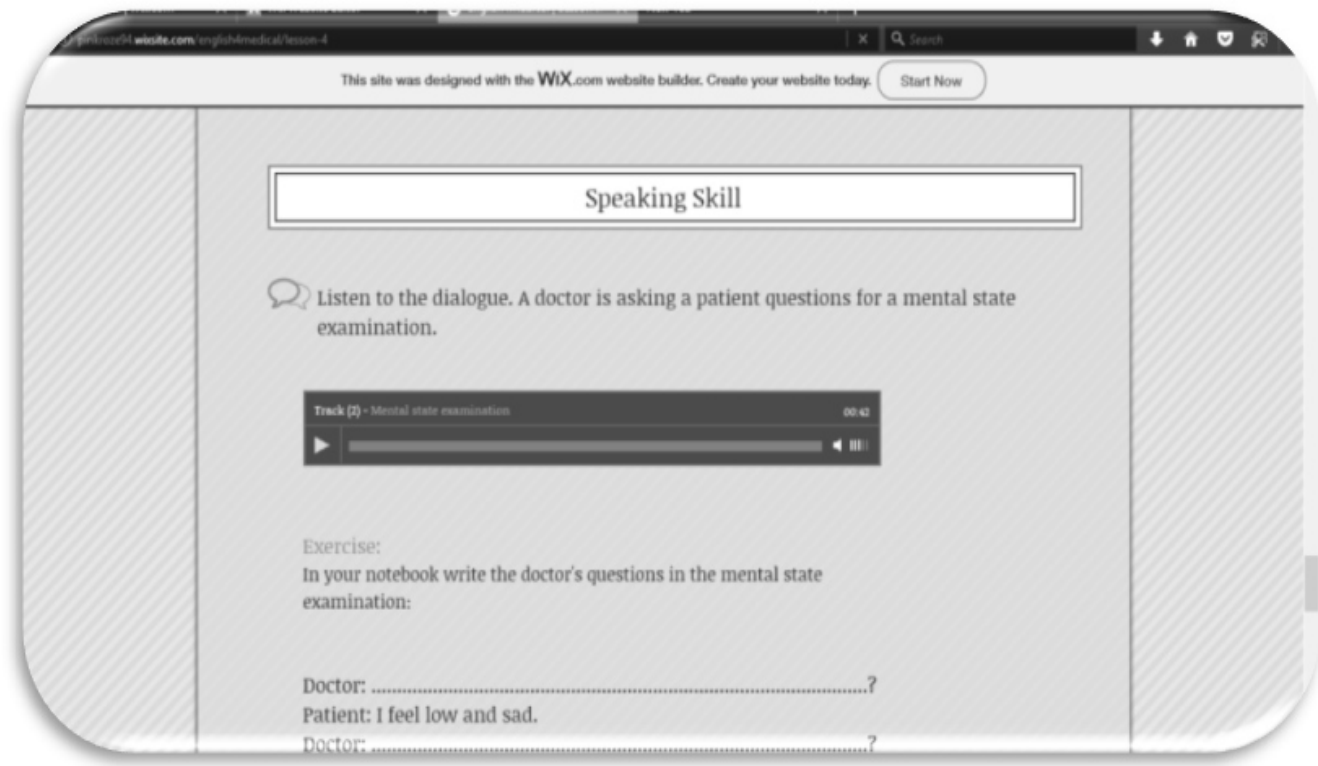

PICTURE (5) 
The last part of the lesson is the speaking skill, where students get to listen to dialogues and to practice how to speak in different medical situations (Picture 5).

The website was created based on the learners needs and only requires basic computer skills; therefore, they can use the website independently by following the instructions. On the other hand, teachers can also use this website as a supplementary tool. Their role would be to guide and instruct the students. Moreover, the materials can be of assistance in teaching Medical students. In addition, they can use the Resources icon to find a variety of materials that were provided to benefit teachers, as well as students.

The materials we provided were taken from medical books and open educational resources. The materials were carefully chosen and considered, we have confirmed their authorship and accuracy. The materials were ordered and organised according to the level of difficulty.

CONCLUSION English for medical purposes plays a significant role for medical students. English has become widely used in Medicine; therefore, the demand to learn EMP has increased. Based on the students' needs to use technology in learning EMP, this paper sheds light on the significance of using the internet, presents a web evaluation and a web design for medical students. Since there is a wide range of learning website, it is important for ESP teachers to be able to conduct a software evaluation procedure that is practical and consistently yields reliable results. However, it can be time consuming to select appropriate websites that match the learners' needs. We have created a website for medical students according to their needs. The website design aimed at covering the main language skills in relation to the medical field. Students would learn medical terminology and how to use them effectively, develop their reading comprehension, writing, listening, and speaking skill. In addition, teachers can use the website partially in their course to increase the motivation of the students. Nevertheless, students can work independently on the website so autonomous learning can be achieved and encouraged.

REFERENCES

Abdullah, G. (2005) Needs of ESP Learners for Practical English Communication: A Case Study of First Year Students at the Medical College, University of Aden (Unpublished Ph.D Thesis). University of Pune, India. 
Dashtestani, R., \& Stojkovic, N. (2015). The Use of Technology in English for Specific Purposes (ESP) Instruction: A Literature Review . The Journal of Teaching English for Specific and Academic Purposes , 435-456.

Day, J. and Krzanwski, M. (2011) Teaching English for Specific Purposes: An Introduction. Cambridge: Cambridge University Press.

Hubbard, P. (2006) Evaluating CALL Software. Calling on CALL: From theory and research to new directions in foreign language teaching, 313-338.

Hutchinson, T., \& Waters, A. (1987), English for Specific Purposes: A learning-centered approach. Cambridge: Cambridge University Press.

Hyland, K. (2002). Specificity revisited: How far should we go now? English for Specific Purposes 21, 385-395.

Kavaliauskiene, G. (2003). Learning ESP on the Internet: Attitudes and Difficulties. English for Specific Purposes Word, Web-based Journal.

Kung, S. C. \& Chuo, T. W. (2002). “Students' Perception of English Learning through ESL/EFL websites." The Internet TESL Journal, 2(1).

Lahti, M., Hätönen, H., Välimäki, M. (2014). Impact of eLearning on nurses' and student nurses' knowledge, skills, and satisfaction: a systematic review and meta-analysis. International journal of nursing studies, 51(1), 136-149.

Lavinia, N. (2017) Teaching ESP through the Internet. Case study. "Ovidius" University Annals, Economic Sciences Series, 17 (1), 183-188.

Levy, M., \& Stockwell, G. (in press). CALL dimensions: Options and issues in computer assisted language learning. Mahwah, NJ: Lawrence Erlbaum.

Pavel, E. (2014). Teaching English for Medical Purpose. Bulletin of the Transilvania University of Braşov, 7(56), 39-46.

Rahman, M. (2015) English for Specific Purposes (ESP): A Holistic Review. Universal Journal of Educational Research, 3(1), 24-31.

Shyamlee, S., \& Phil, M. (2012) "Use of Technology in English Language Teaching and Learning": An Analysis. International Conference on Language, Medias and Culture, vol. 33, 150-156.

Simin, S. (2012). The Role of Internet in ESP Contexts. English for Specific Purposes World, 12(35), 1-16.

Vaiciuniene, V., \& Uzpaliene, D. (2010) Authentic Resources in Technology-based ESP Learning. Studies about Languages, № 17. 94-98.

Vaiciuniene, V., \& Uzpaliene, D. (2012) Authenticity in the Context of Technologically Enriched ESP, Social Technologies, 2(1), 189-201. 


\section{APPENDIX (1): WEBSITE EVALUATION CHECKLIST}

Name of the website: Medical English

URL: http://www.medicalenglish.com

Note: This checklist simply asks for a tick $(\sqrt{ })$, yes/no indications, a response along a Likert scale and some open-ended commentaries.

\section{AUTHORITY AND ACCURACY:}

A. Who is the author of the website?

- I couldn't tell.

- The author is: English 4 Work and the course material written by Mike Mitchell.

B. What authorship clues did the URL (web address) provide?

- Company (.com)

- Academic institution (.edu)

- U.S government agency (.gov)

- Network or computer (.net)

- Non-profit organization (.org)

- Country- specific site (e.g.: .uk)

- Personal webpage (e.g., www.jamieoliver.com)

- Other? Please mention:

C. what are the qualifications of the author or group that created the site?

- I couldn't find this information

- The author(s) qualification: English for Work, a company that specializes in English for Workplace training programs for various industries including: Information technology, hospitality, and accounting.

\section{THE PROGRAM (WEBSITE AND MATERIALS)}

A. Circle YES or NO depending on whether the following components are there or not. 


\begin{tabular}{|l|l|l|}
\hline Program's goals and purposes & Yes & No \\
\hline Tutorial on program's operation & Yes & No \\
\hline Guidance for teachers & Yes & No \\
\hline Guidance for users & Yes & No \\
\hline Reviews of the program & Yes & No \\
\hline Hyperlinks with external resources & Yes & No \\
\hline
\end{tabular}

B. Circle the number that corresponds to your degree of agreement ( 1 is strongly agree, 4 is strongly disagree).

\begin{tabular}{|l|l|l|l|l|}
\hline Materials are organised & 1 & 2 & 3 & 4 \\
\hline Materials are authentic. & 1 & 2 & 3 & 4 \\
\hline Enhancing reading strategies (extensive) & 1 & 2 & 3 & 4 \\
\hline Enhancing vocabulary learning (Academic) & 1 & 2 & 3 & 4 \\
\hline Enhancing writing skills & 1 & 2 & 3 & 4 \\
\hline Enhancing grammar learning & 1 & 2 & 3 & 4 \\
\hline Enhancing listening strategies and note-taking & 1 & 2 & 3 & 4 \\
\hline Enhancing presentations skills (Formal talks) & 1 & 2 & 3 & 4 \\
\hline
\end{tabular}

C. Respond to the following questions by using a few words.

1) How do you describe the home page? (i.e. Simple, attractive, confusing or other, please specify)

The homepage was simple, well designed and informative.

2) How clear are instructions for all users? (straightforward, vague, misleading or other, please specify)

The instructions were very clear and straightforward.

3) How easy are the navigations through the website?

The navigation was simple and easy for the user and there was an icon in all pages that return to homepage.

4) What are the skills that users need in order to use the program (Basic, professional skills).

Basic computer skills are sufficient in order to use this program.

\section{THE TEACHER PERSPECTIVES (TEACHERS AND TEACHING APPROACHES)}

A. Circle YES or NO depending on whether the following components are there or not.

\begin{tabular}{|l|l|l|}
\hline Enough Activities and tasks & Yes & No \\
\hline Hints leading to correct response & Yes & No \\
\hline
\end{tabular}




\begin{tabular}{|l|l|l|}
\hline Feedback to responses & Yes & No \\
\hline Original material required & Yes & No \\
\hline $\begin{array}{l}\text { Collaborative (games, simulations, discussion forums, peer } \\
\text { group writing) }\end{array}$ & Yes & No \\
\hline Facilitative (dictionary, database, tests ) & Yes & No \\
\hline
\end{tabular}

B. Circle the number that corresponds to your degree of agreement ( 1 is strongly agree, 4 is strongly disagree).

\begin{tabular}{|l|l|l|l|l|}
\hline Flexible teaching techniques & 1 & 2 & 3 & 4 \\
\hline Activities serve a pedagogical purpose & 1 & 2 & 3 & 4 \\
\hline Activities challenging and fun & 1 & 2 & 3 & 4 \\
\hline Meaningful rather than mechanical practice & 1 & 2 & 3 & 4 \\
\hline Enhancing linguistic competence (grammar, vocabulary, etc) & 1 & 2 & 3 & 4 \\
\hline Enhancing cultural competence (academic culture) & 1 & 2 & 3 & 4 \\
\hline Modifiability by the instructor & 1 & 2 & 3 & 4 \\
\hline Contextualized discourse & 1 & 2 & 3 & 4 \\
\hline
\end{tabular}

C. Respond to the following questions by using a few words:

1) What is the main role of the teacher in the program? (Facilitator, Guide or Central)

The teachers' role is not essential since students can use the website by themselves.

2) How is the program integrated into the curriculum? (Supplementary, Complementary or Central)

This program can be integrated into the curriculum as supplementary tool.

3) How practical is the process of integration into classroom context?

It can be practical in learning the lesson in the classroom and can be beneficial to use at home as well.

4) What support for teachers is provided?

It is not aimed for teachers but students; however, the material can be of assistance for teachers.

\section{THE LEARNER PERSPECTIVES (LEARNERS AND LEARNING STRATEGIES)}

A. Circle YES or NO depending on whether the following components are there or not. 


\begin{tabular}{|l|l|l|}
\hline Relevance to the target (University students) & Yes & No \\
\hline Focus on academic skills & Yes & No \\
\hline explanation about the learning strategies & Yes & No \\
\hline feedback on the effectiveness of strategy use & Yes & No \\
\hline Explanation about learners' progress & Yes & No \\
\hline Learners have choice of activities & Yes & No \\
\hline Enough time given for task completion & Yes & No \\
\hline Communication among learners enhanced & Yes & No \\
\hline
\end{tabular}

B. Circle the number that corresponds to your degree of agreement ( 1 is strongly agree, 4 is strongly disagree).

\begin{tabular}{|l|l|l|l|l|}
\hline Content likely to be of interest to intended target & 1 & 2 & 3 & 4 \\
\hline Choices depending on learner level & 1 & 2 & 3 & 4 \\
\hline Variety of options to support different types of learners & 1 & 2 & 3 & 4 \\
\hline Variety of topics & 1 & 2 & 3 & 4 \\
\hline Cultural appropriateness & 1 & 2 & 3 & 4 \\
\hline Adaptation to individual differences (interests, learning styles) & 1 & 2 & 3 & 4 \\
\hline Dependant learning & 1 & 2 & 3 & 4 \\
\hline Sufficient practice & 1 & 2 & 3 & 4 \\
\hline
\end{tabular}

C. Respond to the following questions by using a few words

1) What is the level of task difficulty in relation to learners? The level of task difficulty is suitable for intermediate students.

2) How clear are the instructions for learners? The instructions are very clear and direct.

3) How well does the program match learners' expectations and needs?

It contains adequate and beneficial language components that will match learners' expectation and needs.

4) Are there any assessments for learners? If so, what form of assessment is it?

In each unit there are exercises which assess students understanding of the topic and notify them when they make mistake. By passing all 20 units students will receive a certificate.

OVERALL JUDGMENT:

A. Authority and Accuracy (Authors identity and expertise) 
Did the website provide the name of the author?

Did the website provide authorship clues?

Did the website provide the qualification of the author or group that created it?

\begin{tabular}{|l|}
\hline Yes \\
\hline Yes \\
\hline Yes \\
\hline
\end{tabular}

B. The program (website and materials)

How many items are answered by "YES" in YES/NO category $\quad$ 5/6

How many items are answered by " 3 or 4 " in Likert scale

$2 / 8$

What is the general trend of commentaries in the final questions?

The general overview of this program is positive in regard to the programs' materials and design.

C. The teacher perspectives (teachers and teaching approaches)

- How many items are answered "YES" in YES/NO category 1 - 5/6

- How many items are answered " 3 or 4" in Likert scale $1 / 8$

What is the general trend of commentaries in the final questions?

The website is more aimed for learners; however, the websites teaching approach is flexible and can be of use for teachers.

D. The learner perspectives (learners and learning strategies)

\begin{tabular}{|l|l}
\hline How many items are answered by "YES" in YES/NO category & $5 / 6$
\end{tabular}

How many items are answered by "3 or 4" in Likert scale $\quad 0$

What is the general trend of commentaries in the final questions?

The general trend of commentaries shows that the program is very beneficial and sufficient for students' requirements.

THE FINAL DECISION:

Please circle one number in the scale below ( $1=$ disagree, $2=$ agree with some consideration, and 3 = agree)

Do you think that the program is useful to be integrated in your own context? 


\section{COMMENTS AND CONSIDERATIONS:}

From our evaluation of this website it was clear that it is suitable for students of the medical department. It contains all the necessary information and language skills that should be provided for medical students. Therefore, I strongly recommend this website for our own context.

БАСИМ М. АБУБАКЕР ФАРАЏ

\section{ГАДА МОХАМЕД}

УНИВЕРЗИТЕТ У БЕНГАЗИЈУ, ЛИБИЈА

ФИЛОЗОФСКИ ФАКУЛТЕТ, АЛ МАРџ

ДЕПАРТМАН ЗА ЕНГЛЕСКИ ЈЕЗИК И КњИЖЕВНОСТ

РЕЗИМЕ

КРЕИРАњЕ ОНЛАЈН КУРСА ЗА ЕНГЛЕСКИ ЈЕЗИК У МЕДИЦИНИ: ОД ПРОЦЕНЕ ДО НАСТАВНОГ ПРОГРАМА

Енглески језик постао је незамењив у образовном, стручном и пословном контексту, због чега енглески за специјалне намене добија централно место у настави овог језика на терцијарном нивоу учења. Захваљујући интензивном развоју науке и технологије, технолошка средства и ресурси преузимају једну од кључних улога у настави. 3бог све већих захтева студената у том смислу, интернет је постао изузетно значајан извор ресурса за наставу енглеског у медицини. Међутим, избор одговарајућег онлајн извора који одговара потребама како студената тако и наставника понекад може се може претворити у изузетно захтеван и дуготрајан процес.

КљУчнЕ РЕчи: енглески за специјалне намене; енглески у медицини; онлајн учење.

Овај чланак је објављен и дистрибуира се под лиценцом Creative Commons Ауторство-Некомерцијално Међународна 4.0 (CC BY-NC 4.0 |

https://creativecommons.org/licenses/by-nc/4.0/).

This paper is published and distributed under the terms and conditions of the Creative Commons Attribution-NonCommercial International 4.0 licence (CC BY-NC 4.0 | https://creativecommons.org/licenses/by-nc/4.0/). 